\author{
SANG-MI PARK ${ }^{\star}$ Inha University \\ EUN-HEE LEE ${ }^{\star *}$ Inha University \\ KYUNG-JA KIM ${ }^{* * *}$ The Catholic University of Korea \\ HYUN-JUNG YOO**** Chungbook National University \\ KYUNG-WOOK CHA ${ }^{* * * *}$ Sungshin Women's University
}

\title{
A Study of Green Claims in Korean Consumer Market ${ }^{\dagger}$
}

Consumer perception of the meaning of 'green' and 'green products' as well as how they use green claims (including terms, certifications, and marks) should be examined to help consumers pursue green behavior in everyday life. This study investigates what type of green claims prevail in the Korean consumer market and how consumers perceive the meaning of 'green' and green claims. For these purposes, media analysis, in-context research (shop visit) and a survey were conducted to collect green claims (including green terms and certified/noncertified green marks). Green claims in the consumer market were first summarized and analyzed; subsequently, the most frequently used 7 green marks and 15 green terms were selected to construct a consumer survey questionnaire on consumer perceptions of green claims. An online survey was performed via Embrain and the survey

$†$ This study was supported by Inha University.

${ }^{\star}$ Adjunct Professor, Dept. of Consumer \& Child Studies, Inha University, Korea

${ }^{*}$ Corresponding Author: Eun-Hee Lee, Dept. of Consumer \& Child Studies, Inha University, Inha-ro 100, Nam-gu, Incheon, Korea (eunhee@inha.ac.kr)

${ }^{*}$ Professor, Dept. of Consumer \& Child Studies, Inha University, Korea

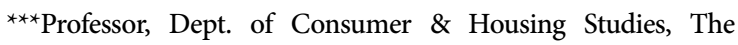
Catholic University of Korea, Korea

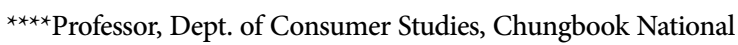
University, Korea

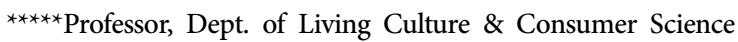
Studies, Sungshin Women's University, Korea

Key Words: green claims, green marks, green terms, green consumption respondents consisted of 500 adult consumers over the age of 20. The field research results showed frequent green claims in the Korean consumer market. However, certified (and hence trustworthy green product information labels) were uncommon in the market. The only green claim widely known and used by consumers was the energy consumption efficiency label. Consumers were interested in the green information label not because it affected their utility cost nor because it was important for environment protection.

Increased concerns for the natural environment exist at most levels of an industrialized global society. These concerns have led to a considerable increase in Green Growth and green consumption. In 2008, the Korean government embraced a vision of 'Low Carbon, Green Growth' as the core of the national new vision. The core of Green Growth is to minimize environmental degradation, climate change, and protect natural resources as well as enable new growth opportunities through environmentally conscious ventures. To achieve green growth, it is crucial to change development approaches from a 'grow first, clean up later' to more responsible longterm attitudes. In addition, consumer support is equally imperative to the development of green technology and the reorganization of systematic legal protection. The green consumption lifestyle of a consumer allow to achieve win-win solutions for consumers, business, and the government sector.

The Korean government has encouraged green consumption in many ways; however, the level of 
consumer green consumption behavior is not yet high (Korea Chamber of Commerce and Industry, 2008; Bae, 2009; Back, 2010; Hwang, 2008). According to research by the Korea Chamber of Commerce and Industry (2008), Korean consumers had a willingness toward green consumption; however, they did not make a conscious effort towards this lifestyle. The main barriers to green product consumption, pointed out by consumers were the lack of diversity, low-quality, and high -price of green products. Bae (2009) and Hwang (2008) showed that consumers were confused by greenwashing advertising in market; subsequently, they distrusted green products and did not want to purchase them.

According to Korean Ministry of Environment (2013), green consumption begins with the purchase of essential products that are essential and environmentally-friendly. Environmentally-friendly products are not harmful to human health but conserve power, fuel, and disposal costs. Environmentally-friendly products require minimal amounts of energy during the whole process of production, circulation, consumption, and disposal. However, defining an environmentally-friendly product is complex. In a strict sense, there is no such thing as a truly sustainable or green product; all consumerproducts that people buy, own, use and discard have a negative environmental impact at some stage in their life-cycle (Cooper, 2000). Products can be classified according to the scale of impact, and a quality threshold can be drawn (Cooper, 2000); physically, products with a low environmental impact from their manufacturing processes to discharge is regarded as an environmentally sustainable product.

Significant research on green consumption or green product consumption by Korean consumers has a primary focus on economic thrift and postconsumption behaviors such as recycling and energy conservation. These curtailment behaviors include water and energy conservation, car use reduction, recycling and responsible waste disposal (Korea Chamber of Commerce and Industry, 2008; Bae, 2009; Back, 2010; Hwang, 2008). In this conceptualization, consumers might narrow the meaning of green consumption as consumption behavior useful to save money on an individual basis, and the environmental effect as a secondary meaning. Related research (Bae, 2009; Back, 2010; Hwang, 2008) found that consumers tend to regard green consumption as an uncomfortable event that involves money, effort, and often low-quality product.

Consumer perceptions on the meaning of 'green' and 'green products' and how they use green claims (including terms, certifications, and marks) should be examined in order to enable the consumer pursuit of green behavior in everyday life. However, according to Consumer Focus (2010), consumers are often unable to determine if a product, package, or service possesses the advertised environmental attributes. They are often confused by many environmental claims on labels and packages; subsequently, there is an ongoing parallel gap between positive attitudes and passive consumer practices towards green consumption. This study has two purposes: 1) to find what kinds of green claims prevail in the Korean consumer market, and 2) to examine how consumers perceive the meaning of 'green' and green claims (certified green marks and green terms). The results reveal an effective presentation method and consumer education plan for required consumer information after the purchase of green products through the identification of the status of the label (mark and phrase) of green products and identifies how consumers recognize and utilize green product information.

\section{LITERATURE REVIEW}

\section{The Concept of Green Consumption}

The green issue has been become an important issue in global society, terms such as 'green', 'eco', 'environment friendly' have been widely used to refer to something good for the environment. However, there is no unique consensus on what is really green or good for the environment. For example, the meaning of 'good' or 'environment' varies by different people and different societies. Based on related research, the term "green consumption" usually covers a range of activities in consumption fields, that includes the purchase of green products, recycling materials, the efficient use 
Table 1. Sub-components of Green Consumption

\begin{tabular}{ll}
\hline Components & Definition \\
\hline Environment friendly & $\begin{array}{l}\text { Greenhouse gas reduction, prohibition of hazardous substances and pollutants release, separate discharge, control } \\
\text { of disposables, purchase of recycled/reused products }\end{array}$ \\
Green energy & $\begin{array}{l}\text { Renewable energy (solar/geothermal/wind/hydrogen energy), fuel cell, Reduction of fossil energy, energy recovery } \\
\text { and circulation }\end{array}$ \\
Physical safety & $\begin{array}{l}\text { No use of harmful substances for human body, safe and qualitative foods, reduction of chemical synthesis, hazard } \\
\text { management }\end{array}$ \\
Substantiality & $\begin{array}{l}\text { Harmony between human and nature, harmony between development and preservation, waste reduction, preserva- } \\
\text { tion of farm land }\end{array}$ \\
\hline
\end{tabular}

Reference : Yoo et al. (2011)

of energy, environmental protection, and the preservation of species (Kye \& Kang, 1998; Bae, 2009; Huh, 2009). Sometimes it is defined as the five "R's": reduce, reevaluate, reuse, recycle, and rescue.

There is no clear definition in Korea on the concept of green consumption even though the Korean government has organized various laws and regulations such as - Law of Low carbon green Growth' and 'Law of Promoting Green Products. The contents of green consumption can be inferred by a review of the clauses related to many environmentrelated laws and regulations enacted to promote the green behavior by consumers and producers. Yoo et al. (2011) found that there were 4 sub-components of green consumption after analyzing 23 greenrelated Korean laws and regulations (Table 1). The result shows that the consumption of organic farm products as well as energy saving-consumption lower the carbon footprint and recycling costs subsequently. It is regarded in the green consumption domain.

Federal Trade Commission (FTC) of U. S. A. and Department for Environment, Food, and Rural Affairs (DEFRA) of England, are famous for their endeavors to promote green consumption; however, they do not provide a clear definition of green consumption. The meaning and range of green consumption are inferred by the categories that they address and regulate. The Green Guides FTC (1992) issued in 1992 was to help marketers ensure that the claims they made regard to green issues were true and substantiated. Marketers have expanded their promotion of the environmental attributes of their products and services because consumers have become increasingly concerned about the environ- mental impact of the products and services they use. A periodic review of the FTC showed that consumers were confused about environmental claims and could not determine the environmental attributes. The FTC admitted that the 'qualified general claims of environmental benefits are difficult to interpret and dependent on their context' under the FTC Act; subsequently, it enforces marketing claims on a case-by-case basis. The guidance they provide were 1) degradable, 2) compostable, 3) recyclable, 4) recycled, 5) ozone-safe and ozonefriendly, 6) free of additives and non-toxic. Claims over the general substantiality, organic/natural, renewable/renewable energy, and carbon-offset are not addressed in Green Guides

The Green Claims Guidance of DEFRA is designed for institutions that produce, sell, market or advertise products (or services) in the UK and for people who make environmental claims about the products. This guidance promotes the use of clear, accurate, and relevant claims on environmental attributes in the market; however, this guidance does not define what is green consumption or a green product but it suggests what environmental terms should be used with the evidence in Annex 5. Example of the environment terms are: compostable, degradable, designed for disassembly, extended life product, recovered energy, recyclable and recycled content, reduced energy consumption, reduced resource use, reduced water consumption, reusable and refillable waste reduction, carbon footprint, carbon neutral, and renewable energy.

\section{Green Consumption and Green Claims}

Consumers should know what was green products 
and green consumption behavior in order to realize green consumption. First the government should provide accurate and reliable green information that represent the environmental aspect of products or services. In this context, the Korean government has induced eco-friendly consumption patterns by providing environment information about products and services to consumers. In addition, it has introduced and enforced environmental labeling that enables producers to develop and produce products based on eco- friendly patterns.

The International Organization for Standardization classified environment labeling into 3 types and specified the requirements of environment labeling by type included in the ISO 14020 series. Among them, Type II environment labeling (ISO 14021) is the mark or phrase to be attached with the purpose to promote products such as eco-friendly products by producers or retailers. It is certified through a self-declaration on environmental attributes not by third parties, but by producers (or sellers) who take responsibility for the prevention of false and deceptive advertising. Green marketing universally has a positive effect on the creation of an ecofriendly image for enterprises and the growth of sales; therefore, the number of enterprises of an ecofriendly image to products tends to increase. For example, obscure eco-friendly activities that shows an overt eco-friendly policy or image are called greenwashing if they are not eco-friendly or proven. The increase of greenwashing induces consumers to misunderstand and make wrong purchase decisions on green products that show eco-friendly attributes; subsequently, it causes consumer problems. Greenwashing interferes with the right of consumers to receive information and produces cost and the problem of responsibility for reliability (Lee, Hwang,
\& Kim, 2010).

The Korean government and many other institutions have developed several types of green product marks in regards to international environment labeling regulations. Table 2 shows some of the representative marks.

Systems related to green consumption practice information include the Environment Mark System (Ministry of Environment and Korea Environmental Industry \& Technology Institute), Environmental Declaration of Product (Ministry of Environment), Carbon Labeling System (Ministry of Environment, Korea Environmental Industry \& Technology Institute), Energy and Recycling Mark (Energy management corporation and Korean Agency for Technology and Standards).

The Environmental Mark System provides accurate environmental information to consumers about products and encourages companies to develop and produce products based on eco-friendly consumption patterns by labeling products that can produce relatively less pollution during the product life-cycle and conserve resources and energy compared to other products of the same purpose. Ministry of Environment enacted provisions and enforcement regulations on the operation of the Environment Mark System in April 1992. The past environmental mark known as 'clearer and greener' was used from April 1992 to July 2004. The new environmental mark (Table 2) has been used since August 2004.

\section{Green Consumption Behavior of Consumers}

The Korean government has encouraged green consumption in many ways; however, the level of green consumption behavior by consumers is low (Korea Chamber of Commerce and Industry, 2008;

Table 2. Product Information Labels in Korea

\begin{tabular}{|c|c|c|c|c|c|c|c|}
\hline Name & Eco label & $\begin{array}{c}\text { Organic Foods } \\
\text { label }\end{array}$ & $\begin{array}{c}\text { Environmental } \\
\text { declaration products }\end{array}$ & $\begin{array}{l}\text { Carbon } \\
\text { labelling }\end{array}$ & $\begin{array}{l}\text { Energy consumption } \\
\text { efficiency }\end{array}$ & $\begin{array}{l}\text { Energy saving } \\
\text { products }\end{array}$ & $\begin{array}{l}\text { Good recycled } \\
\text { products }\end{array}$ \\
\hline Year from & 1992 & 1992 & 2001 & 2009 & 1992 & 1998 & 1997 \\
\hline Mark & & & & & & & \\
\hline
\end{tabular}


Bae, 2009; Back, 2010; Hwang, 2008). The Korea Chamber of Commerce and Industry (2008) surveyed 500 adults living in Seoul and found that $85 \%$ the respondents practice green consumption; however, only $50 \%$ of respondents implemented their philosophy. Consumers in their 50s and 60s participated in green consumption more than other consumers and female and high-income consumers practiced green consumption more than male and low-income consumers, respectively. Bae (2009) researched 1000 homemakers living in 6 metropolitan cities and investigated their attitudes and behaviors toward green consumption. The results showed that the attitude score of respondents was adequate, but the practice score was 50.6 and showed that they did not actively practice green behavior. The score of 50.6 was far lower than the average score of developed countries, which was 71.5. The most wellpracticed behaviors were separating waste disposal and the use of insulator.

Next, The barriers to green consumption were examined. The main consumer barriers against the consumption of green products according to the Korea Chamber of Commerce and Industry (2008) were the lack of diversity, low quality and high price of green products, and distrust of green products. Bae (2009) also examined similar barriers such as distrust of green products, high price, lack of time to browse green products, no support by family members, and lack of diversity. The Boston Consulting Group summarized 8 reasons why people did not choose green products very well (Moon, 2010). They were 'not relevant for my needs', 'do not know what it is', 'do not know where to find it, 'not enough variety', 'prefer to other brands', 'back of trust', 'lesser quality', and 'high-price'.

Barriers to green consumption were consumer's unawareness and distrust of green products. The Korean government has tried to promote green consumption with several kinds of green product information (Bae, 2009, Lee, 2000, Hwang, 2008); however, Korean consumers did not know what they were and tend to only use green information except for energy consumption efficiency labels. According to the study by Kim (2012), 81.9\% of the respondents have seen environmental mark; however, cases that recognized environmental mark symbols correctly were only $45.8 \%, 33.3 \%$ and $19.7 \%$ of respondents that correctly recognized environmental mark, energy saving marks and carbon mark, respectively. In addition, the experience to purchase products with environmental marks after recognizing the environmental mark symbols was only $39.6 \%$. The study by Kang (2009) found a relatively low consumer awareness and understanding on voluntary environment marks that did not impose a mandatory consumer labels and environment marks on information delivery type that include professional information. Individuals purchased the products using green consumption information in the case of consumers who were aware of accurate contents about environment mark system; however, Korean consumers did not utilize environment marks and green consumption information well.

\section{RESEARCH METHOD}

\section{Research Questions}

The first question was what kind of green claims prevail in the Korean consumer market. The second question was what are the consumer perceptions of green consumption and green claims. It is important to analyze how consumers perceived the meaning of 'green' when they think about green consumption and how aware consumers are when they utilize green marks and green terms.

\section{Data Collection and Survey Tools}

The media analysis and in-context research (Shop visit) identified what kinds of green claims prevailed in the consumer market. All possible displayed green claims and presented products, that consumers routinely encounter in the market, were investigated. The problems of misuse and abuse were subsequently analyzed after the identification of green claims in print media and broadcast advertising. The target media published advertising in five daily newspapers (Chosun Ilbo, JoongAng Ilbo, Dong-A Ilbo, Hankyoreh Newspaper and Kyunghyang Newspaper) on May $24^{\text {th }} 2010$ and all advertising by two broadcasters (SBS and MBC) from 6:00 AM on May 
$29^{\text {th }} 2010$ to AM 2:00 on May $30^{\text {th }} 2010$. Product groups, brand, used mark and advertising copies related to green claims from all print advertising and broadcast advertising were recorded and analyzed.

Through in-context research (Shop Visit), various information of green claims displayed on products were identified and analyzed. The green claims included green terms, certified and non-certified marks, and other images. The target stores were three department stores (Shinsegae, Lotte and Hyundai) and three large discount outlet stores (EMart, Homeplus and Lotte Mart). A total of 28 pretrained college students participated in the media analysis and shop visits with one group of two people. Prior to the research, they were taught about green consumption for an hour and were asked to collect any product information that they thought was related to a green claim. The duration of the onsite survey was two weeks from the end of May to early of June.

A survey was conducted to investigate consumer perceptions of green claims after the identification of the green claims in the consumer market. In the survey, the first question was to analyze what consumers perceived as 'green' when they said green consumption. The next question was to understand the level of consumer awareness, utilization and trust of green claims. To examine the level of awareness, 7 certified green marks and 15 green claim terms were selected from multiple green claims and were used to construct survey questionnaires. An online survey was performed via Embrain (www.embrain.com) in July, 2010 and survey respondent were 500 adult consumers over the age of 20. In terms of Age, the ratio from $20 \mathrm{~s}$ to $50 \mathrm{~s}$ was almost identical. In the case of educational level, college graduates were $56.6 \%$, which was the most common, followed by high school graduates at $25.4 \%$ and 2-year college graduates at $16.2 \%$. In terms of the average monthly household income, 4,050,000 won a month was the most common. Those who took eco-friendly education were $12.2 \%$. In terms of occupation of survey targets, office workers and civil servants, the homemakers and the self-employed were $45.4 \%$, $20.6 \%$ and $13.2 \%$, respectively.

\section{RESULTS AND DISCUSSION}

\section{Green Claims Prevailing in the Market}

\section{1) Media Analysis}

\section{(1) TV advertising analysis}

Table 3 shows the total number of TV advertisings and the number of advertised or displayed green claims. The total number of broadcast advertisements was 698 and the number of advertisements that included information related to green consumption was 97, which accounted for $13.9 \%$. MBC had a slightly higher ratio of advertisements related to green claims compared to SBS.

Upon summarizing the green claims of TV advertising, most claims were related to food (beverages, yogurt, chewing gum, agricultural products, chicken, health food, condiments, ham, cheese, cold noodles, and powdered milk), pharmaceuticals, cosmetics, and home appliances (washing machines, air conditioners, water purifier and air cleaners) (Table 4). The contents of green claims emphasized the use of natural materials and natural ingredients such as natural pigments, natural materials, botanical ingredients, natural fermentation, herbal raw materials and spring water. The emphasis on organic, such as additives $0 \%$, no additives and no coloring was also followed. In addition, the term 'eco-friendly' was widely used in food, housing, and other products.

Table 3. Total Number of TV Advertising and Percentage (\%) of Advertising with Green Claims

\begin{tabular}{cccccc}
\hline \multicolumn{2}{c}{ SBS } & \multicolumn{2}{c}{ MBC } & Total \\
\hline $\begin{array}{c}\text { Total No. of } \\
\text { advertisements }\end{array}$ & $\begin{array}{c}\text { Advertisement with } \\
\text { green claims (\%) }\end{array}$ & $\begin{array}{c}\text { Total No. of adver- } \\
\text { tisements }\end{array}$ & $\begin{array}{c}\text { Advertisements } \\
\text { with green claims (\%) }\end{array}$ & $\begin{array}{c}\text { Total No. of Adver- } \\
\text { tisements }\end{array}$ & $\begin{array}{c}\text { Advertisements } \\
\text { with green claims (\%) }\end{array}$ \\
393 & $52(13.2)$ & 305 & $45(14.8)$ & 698 & $97(13.9)$ \\
\hline
\end{tabular}


Table 4. Contents of Monitoring Information Related to Green Claims in TV Advertising

\begin{tabular}{|c|c|c|c|}
\hline Product type & Name & Number & Used phrase \\
\hline \multirow{5}{*}{ Food } & Beverages, yogurt, chewing gum & 13 & \multirow{5}{*}{$\begin{array}{l}\text { Natural pigment, natural material, additives } 0 \% \text {, no addition, } \\
\text { organic, eco- friendly, domestic, no pigment seven star rating, low } \\
\text { calorie, natural ground water, LOHAS certification, no addition of } \\
\text { sugars ( } 1 \text { step), reducing sugar, raw brown rice natural fermenta- } \\
\text { tion }\end{array}$} \\
\hline & Agricultural products, chicken & 7 & \\
\hline & Health food & 6 & \\
\hline & Condiments & 6 & \\
\hline & $\begin{array}{l}\text { Ham, cheese, cold noodles, } \\
\text { powdered formula }\end{array}$ & 7 & \\
\hline \multirow{5}{*}{$\begin{array}{l}\text { Housing and home } \\
\text { appliances }\end{array}$} & Apartments & 2 & \multirow{5}{*}{$\begin{array}{l}\text { Eco-friendly, energy consumption efficiency first rating, energy } \\
\text { monitor, sterilizing system, eco, hazardous material removal, anti- } \\
\text { virus }\end{array}$} \\
\hline & Paint & 1 & \\
\hline & Windows & 3 & \\
\hline & $\begin{array}{l}\text { Washing machines, air condition- } \\
\text { ers }\end{array}$ & 9 & \\
\hline & Air cleaners, water purifiers & 6 & \\
\hline \multirow{2}{*}{$\begin{array}{l}\text { Pharmaceuticals and } \\
\text { cosmetics }\end{array}$} & Pharmaceuticals & 9 & \multirow{2}{*}{$\begin{array}{l}\text { Botanical ingredients, natural raw material, herbal ingredient, Love } \\
\text { Eco, nature with high purity }\end{array}$} \\
\hline & Cosmetics & 7 & \\
\hline \multirow{4}{*}{ Miscellaneous goods } & Detergent & 3 & \multirow{4}{*}{$\begin{array}{l}99.9 \% \text { sterilization, anti- bacterial, herb medicine extract, pure cot- } \\
\text { ton texture, natural fibers }\end{array}$} \\
\hline & Toothpaste & 2 & \\
\hline & Wet tissue, sanitary pads & 2 & \\
\hline & Deodorants, home mats, desiccant & 5 & \\
\hline \multirow[t]{2}{*}{ Others } & Enterprise & 4 & $\begin{array}{l}\text { Nature conservation, healthy earth, eco-friendly future technology, } \\
\text { sincerity protecting earth }\end{array}$ \\
\hline & Energy & 2 & Good energy \\
\hline
\end{tabular}

Table 5. Total Number of Newspaper Advertisements and Number of Advertisements Related to Green Claims

\begin{tabular}{|c|c|c|c|c|c|}
\hline Name of newspaper & $\begin{array}{l}\text { Total number of } \\
\text { advertisements }\end{array}$ & $\begin{array}{l}\text { Number of } \\
\text { advertisements with } \\
\text { green claims }\end{array}$ & Newspaper name & $\begin{array}{l}\text { Total number of } \\
\text { advertisements }\end{array}$ & $\begin{array}{c}\text { Number of } \\
\text { advertisements } \\
\text { with green claims }\end{array}$ \\
\hline Dong-A Ilbo & 74 & 5 & JoongAng Ilbo - general & 61 & 5 \\
\hline Chosun Ilbo - general & 43 & 4 & Hankyoreh newspaper - general & 40 & 1 \\
\hline Kyunghyang newspaper & 16 & 0 & & & \\
\hline Total & & & & 234 & 15 \\
\hline
\end{tabular}

(2) Analysis of newspaper advertising

The total number of newspaper advertisement was 234 and the number of advertisements that contained green claims was 15 , which accounted for $6 \%$ (Table 5). The ratio of newspaper advertising (which included green claims) was lower than that of TV advertising. The green claims in newspaper advertisement included many green marks, certificates, and green terms and phrases. These were divided into 4 factors of Mark, Green-term 'Ecofriendly', Energy, and Low carbon. Table 6 shows the green marks, terms, and phrases.
An analysis of media advertising showed many non-certified marks with green claims; subsequently many of them were unclear in regards to certification. For example, there might exist an image or phrase alluding to organic, but no organic mark was displayed. There was also a display showing it had that it was made of eco-friendly agricultural products, but it had no certification. It looked similar to existing certified marks, but the color or design was slightly different from certified ones. There were many green claims that use natural \& organic words and images without certification marks. 
Table 6. Green Claims in Newspaper Advertisements

\begin{tabular}{ll}
\hline \multicolumn{1}{c}{ Theme } & \multicolumn{1}{c}{ Used marks and phrase } \\
\hline Marks & $\begin{array}{l}\text { Korea LOHAS Certification, medical device manufacturing management standards (GMP), FDA Registration, } \\
\text { international environment management certification, Air Cleaning Association Certification, environment research } \\
\text { institute certification, product safety autonomic implementation, green Korea (2009 eco-friendly energy product } \\
\text { Small and Medium Business Administrator award) }\end{array}$ \\
\hline Term: Eco- friendly & $\begin{array}{l}\text { Eco- friendly / organic foods, health related to blocking electromagnetic wave and hazardous substances, Venerabil- } \\
\text { ity from nature, vegetable ingredient 40 years, well- being technology, organic, natural raw material vitamins, non- } \\
\text { toxicity to the human body, blocking electromagnetic waves, removal of microorganisms causing disease, triple } \\
\text { safety devices }\end{array}$ \\
\hline Energy & $\begin{array}{l}\text { High- efficiency energy, Energy savings, alternative energy, recycling, Fuel cell, good energy, Smart eco system } \\
\text { implementing the world's lowest consumption power 31.8 (kWh/ month) }\end{array}$ \\
& $\begin{array}{l}\text { Energy saving - little electricity bill. Longer life of light bulb. } \\
\text { Eco- friendly - it do not use mercury and gas for ignition. Eco-friendly energy product }\end{array}$ \\
\hline Low carbon & $\begin{array}{l}\text { Environment Mark: Low carbon, Green consumption, Sustainable } \\
\text { Environment Support, Low Carbon Green Growth Committee, Green Start Network, Establishment of Eco Green } \\
\text { Campus of Low Carbon and green growth, Clean Campus Movement, Nature Friendly Research Equipped with } \\
\text { Removal Function of Environment Harmful Substances, } \\
\text { Technology received the highest ratings of the global eco-friendly certified LEED }\end{array}$ \\
\hline
\end{tabular}

2) In- Context Research (Shop Visit). Due to the results of on-site studies, the collected green claims were classified by certification marks, green terms, and phrases (Table 7 and 8).

\section{(1) Green Mark Analysis}

Table 7 shows the green marks (multiple response) prevailing in the market. A total of 27 kinds and 239 cases of the certification marks were collected. Food of 6 kinds, low carbon of 4 kinds, energy of 6 kinds, recycling of 4 kinds, ISO series of 1 species and others of 6 kinds (items were counted as separate ones if they were found on different brand or different products even if it was the same certification mark). Among the 239 cases of certification marks, a total of 213 cases and 26 cases were classified into domestic marks (certified by domestic institution) and overseas certification marks (certified by overseas institution), respectively. Among the domestic certification marks, a total of 153 cases were national certification marks and 28 cases were association certification marks. In addition, the certification marks of a company or marks of unclear accreditation agencies represented 32 cases. In the case of overseas certification marks, national organization certification marks were 7 cases and the association certification marks were 14 cases. A total of 5 cases were certification marks where it was impossible to identify other accreditation agencies.

In the Food Sector, there were 6 kinds of certification marks such as organic, HACCP, no additives, and agricultural food geographical labeling, excellent agricultural product certification and LOHAS. Among them, organic related certifications had 43 cases, which were the most common and HACCP related certifications were 22 cases, which was the second largest. In Food Sector, most accreditation organizations were from the national government in regard to domestic certification marks. In the case of overseas certification marks, association certifications were 11 cases, which was slightly more than the national government certification that had 7 cases. In the case of the Eco-Friendly Mark, there were four species such as Eco-Friendly Mark, EDP, labeling of carbon emissions and products labeled low carbon; however, EDP was not found. In addition, most accreditation organizations were association certification (eco-friendly product promotion agencies). Certification marks related to carbon were also $100 \%$ of the national certification. In the case of recycling, recycling goods that use the GR mark, reusable mark and recycling mark (separate emission) were included; however, nothing except recycling (separate emission) had been found. Recycling separate emission marks was $100 \%$ of the national certification mark and overseas recycling related marks were not found.

An examination of the content of labeled marks in detail showed that food, cosmetics, other various miscellaneous goods and household goods had 
Table 7. Status of Eco- Friendly Related Marks (Multiple Responses)

\begin{tabular}{|c|c|c|c|c|c|c|c|c|}
\hline \multirow{2}{*}{ Classification } & & \multicolumn{3}{|c|}{ Domestic certification } & \multicolumn{3}{|c|}{ Overseas certification } & \multirow{2}{*}{ Total } \\
\hline & & A & B & $\mathrm{C}$ & A & B & $\mathrm{C}$ & \\
\hline \multirow{6}{*}{$\begin{array}{l}\text { Food } \\
\text { (6 species) }\end{array}$} & Organic & 10 & & 11 & 7 & 11 & 4 & 43 \\
\hline & HACCP & 22 & & & & & & 22 \\
\hline & No additives & & 1 & & & & & 1 \\
\hline & Agricultural food geographical labeling & 1 & & & & & & 1 \\
\hline & Excellent agricultural products certification & 5 & & & & & & 5 \\
\hline & LOHAS & & 13 & & & & & 13 \\
\hline \multirow{4}{*}{$\begin{array}{l}\text { Flow carbon } \\
\text { ( } 4 \text { species })\end{array}$} & Eco- Friendly mark & 60 & & & & & & 60 \\
\hline & EDP & & & & & & & 0 \\
\hline & Labeling of carbon emissions & 7 & & & & & & 7 \\
\hline & Products labeling low carbon & 2 & & & & & & 2 \\
\hline \multirow{6}{*}{$\begin{array}{l}\text { Energy } \\
\text { (6 species) }\end{array}$} & Energy consumption efficiency rating & 3 & & & & & & 3 \\
\hline & Energy saving mark & 3 & & 1 & & & & 4 \\
\hline & Minimal consumption efficiency satisfaction & & & & & & & 0 \\
\hline & High efficiency energy & & & 1 & & & & 1 \\
\hline & Standby power use & & & & & & & 0 \\
\hline & Standby power warning Labeling & & & & & & & 0 \\
\hline \multirow{4}{*}{$\begin{array}{l}\text { Recycling } \\
\text { (4 species) }\end{array}$} & Use of recycling goods & & & & & & & \\
\hline & GR mark & & & & & & & 0 \\
\hline & Reusable & & & & & & & 0 \\
\hline & Recycling (separate emission) & 40 & & & & & & 40 \\
\hline ISO series & & & 6 & & & & & 6 \\
\hline \multirow{6}{*}{$\begin{array}{l}\text { Others } \\
\text { (6 species) }\end{array}$} & Organic, bio, eco & & & 13 & & & 1 & 14 \\
\hline & Hygiene, safety mark & & 3 & & & & & 3 \\
\hline & CS (clean \& safety) & & & & & & & 0 \\
\hline & Blocking electromagnetic waves & & 1 & & & & & 1 \\
\hline & No bleach, no fluorescence & & & & & & & 0 \\
\hline & Hazardous substance, allergy, no irritation & & 4 & 6 & & 3 & & 13 \\
\hline Total & & 153 & 28 & 32 & 7 & 14 & 5 & 239 \\
\hline
\end{tabular}

A : National certification B: Association certification C: Company's own, impossible to be identified

various marks representing green products with mixed certification marks and non-certification marks; subsequently, too many marks were extensively used. In the food sector, marks related to organic and marks representing organic existed very randomly; however, most cases had different colors or did not have a specific letter or specific labeling compared to existing certification marks.

There were significant numbers of overseas certification marks, individual company marks and non-certification marks of unknown accreditation agencies. In addition to accreditation agency, certification validity period or certification contents were mostly unclear. Organic products had no description of which ingredients were included in the organic raw materials or the amount. We encountered a significant number of products with the individual marks of each company, which were not certified. It was likely that consumers could make a wrong decision based on the inaccurate information of these marks. 
Table 8. Types of Eco-friendly Claims and Terms

\begin{tabular}{|c|c|c|c|c|c|c|c|c|}
\hline & Food & $\begin{array}{l}\text { Clothing, } \\
\text { cosmetics, } \\
\text { bedding }\end{array}$ & $\begin{array}{l}\text { Automotive/ } \\
\text { supplies }\end{array}$ & $\begin{array}{c}\text { Furniture/ } \\
\text { office sup- } \\
\text { plies }\end{array}$ & $\begin{array}{l}\text { Housing/ } \\
\text { housing sup- } \\
\text { plies }\end{array}$ & $\begin{array}{l}\text { Kitchen/ } \\
\text { household } \\
\text { appliance }\end{array}$ & $\begin{array}{l}\text { Personal } \\
\text { belongings } \\
\text { (detergent, } \\
\text { shampoo) }\end{array}$ & Total \\
\hline Eco- friendly & $7(6.4)$ & $13(27.1)$ & $10(18.5)$ & $9(42.9)$ & $15(25.4)$ & $6(20.0)$ & $4(13.3)$ & $64(18.2)$ \\
\hline Nature & $4(3.6)$ & $4(8.3)$ & $1(1.9)$ & & $2(3.4)$ & & $2(6.7)$ & $13(3.7)$ \\
\hline Natural & $2(1.8)$ & $7(14.6)$ & $10(18.5)$ & $1(4.8)$ & & & $2(6.7)$ & $22(6.3)$ \\
\hline Green & & $1(2.1)$ & $3(5.6)$ & $1(4.8)$ & $1(1.7)$ & $1(3.3)$ & $1(3.3)$ & $8(2.3)$ \\
\hline Eco & & $3(6.3)$ & $5(9.3)$ & $1(4.8)$ & $1(1.7)$ & $3(10.0)$ & & $13(3.7)$ \\
\hline Organic & $50(45.5)$ & $8(16.7)$ & & & & & $2(6.7)$ & $60(17.0)$ \\
\hline Clean & $3(2.7)$ & & $2(3.7$ & & $1(1.7)$ & & & $6(1.7)$ \\
\hline Energy saving & & & $3(5.6)$ & & $7(11.9)$ & $2(6.7)$ & & $12(3.4)$ \\
\hline Fuel efficiency & & & $3(5.6)$ & & $7(11.9)$ & $3(10.0)$ & & $13(3.7)$ \\
\hline Carbon emission & & & $1(1.9)$ & $1(4.8)$ & & & & $2(0.6)$ \\
\hline ISO Series & $3(2.7)$ & & & & $1(1.7)$ & & & $4(1.1)$ \\
\hline $\begin{array}{l}\text { Reuse / separate } \\
\text { emission }\end{array}$ & & & & $1(4.8)$ & $2(3.4)$ & & $2(6.7)$ & $5(1.4)$ \\
\hline $\begin{array}{l}\text { Environment con- } \\
\text { servation }\end{array}$ & $4(3.6)$ & & & $1(4.8)$ & $1(1.7)$ & $2(6.7)$ & $1(3.3)$ & $9(2.6)$ \\
\hline $\begin{array}{l}\text { Sustainability / new } \\
\text { renewable energy }\end{array}$ & & & & & $5(8.5)$ & & & $5(1.4)$ \\
\hline Pollution reduction & & $2(4.2)$ & $2(3.7)$ & & $7(11.9)$ & & $2(6.7)$ & $13(3.7)$ \\
\hline $\begin{array}{l}\text { Human body safety } \\
\text { / peace of mind / } \\
\text { non toxicity / haz- } \\
\text { ardous substance }\end{array}$ & $1(0.9)$ & $5(10.4)$ & $10(18.5)$ & $5(23.8)$ & $5(8.5)$ & $11(36.7)$ & $5(16.7)$ & $42(11.9)$ \\
\hline $\begin{array}{l}\text { No pesticides / no } \\
\text { pollution / no harm }\end{array}$ & $20(18.2)$ & & & & $7(11.9)$ & & & $20(5.7)$ \\
\hline $\begin{array}{l}\text { No additives / no } \\
\text { fluorescence }\end{array}$ & $13(11.8)$ & $3(6.3)$ & & & $5(8.5)$ & & $8(26.7)$ & $24(6.8)$ \\
\hline $\begin{array}{l}\text { Anti-bacterial/ } \\
\text { hygiene }\end{array}$ & & & & $1(4.8)$ & $2(3.4)$ & $2(6.7)$ & & $5(1.4)$ \\
\hline Wellbeing & $1(0.9)$ & $2(4.2)$ & $1(1.9)$ & & $2(3.4)$ & & $1(3.3)$ & $7(2.0)$ \\
\hline Others & $2(1.8)$ & & $3(5.6)$ & & & & & $5(1.4)$ \\
\hline Total & $110(100.0)$ & $48(100.0)$ & $54(100.0)$ & $21(100.0)$ & $59(100.0)$ & $30(100.0)$ & $30(100.0)$ & 100.0 \\
\hline
\end{tabular}

(2) Table 8 shows green terms and phrases results in the sectors of food, clothing, automotive, furniture and office supplies, housing and housing supplies and personal belongings. First, the most frequently used claim term was 'eco-friendly' at $18.2 \%$ of the total, 'Organic' followed with $17.0 \%$, and 'Human body safety/ peace of mind/ non- toxicity/ hazardous substance' followed $11.9 \%$.

In food advertising, 'organic' was the most common term when viewed as groups of products There were some cases that used only 'organic product' or 'corn organic'; in addition, there were many expressions with no pigment, no preservatives and no agricultural pesticides. There were some expressions of eco-friendly and LOHAS. In clothing and miscellaneous goods, the most commonly expressed terms were green terms such as 'ecofriendly', 'organic' and 'natural' In automotive and automotive supplies, there were many expressions in terms such as 'eco-friendly', 'natural', 'human body safety, peace of mind, non-toxicity, and hazardous substance. The expression of 'RoHS (restriction of 
hazardous substances) eco-friendly' was mainly used for furniture and office supplies. In housing advertising, expressions (where materials for housing were eco-friendly) and energy saving parts (fuel and saving water) were eco-friendly and were mainly used since they reduced pollution and made products reusable. In personal belonging advertisements, various expressions related to green emerged. Expressions of organic materials, natural materials and natural ingredients (even natural derived ingredients) were common. In addition, expression such as no fluorescence, no bleach and no smell were common. In addition, there were interesting expressions such as carbon cash back product, ozone layer preservation and eco-friendly wellbeing.

The term of 'eco-friendly' were widely used regardless of items. It was found that eco-friendly claims and the use of the term varied slightly depending on the items. In addition, the term for eco-friendly claims was sometimes used in conjunction with eco-friendly related marks; however, many cases had a company's own environmental self-claims.

\section{Consumer Perceptions of Green Consumption and Green Claims}

1) Consumer perceptions of Green consumption Green consumption is generally defined as 'when purchasing goods and services, the consumption motive is the purchase of eco-friendly products in consideration of the environment, the reduction of carbon emissions, and the efficient use of resources (Bae, 2010). However, the identification of consumer awareness on green consumption through a survey indicated that consumers understand the concept of green consumption to be "helpful to macro environment to prevent climate change" as well as ultimately helpful for the health and safety of consumers in the category of green consumption.

Table 9 shows that, among survey targets of 500, the meanings of green consumption over $40 \%$ of respondents select were 'consumption to prevent the environmental pollution', 'consumption which is helpful for health of me and my family', 'consumption to discharge carbon less', 'consumption saving and consumption to use goods long', 'consumption to use natural materials and natural ingredients' and 'reuse of resources and consumption of recycled products' However, the ratio of consumers that selected 'consumption not to affect climate change' was only $25.8 \%$. This implied that consumers do not clearly classify the macro environment and proximity environment (living village or housing environment, close living environment) when talking about environment direction. When they actually choose a certain selection based on green consumption, it was more likely that they favor the proximity environment (for example, health of me and my family) rather

Table 9. Concept of Green Consumption that Consumers are Aware of (Multiple Responses)

\begin{tabular}{|c|c|c|c|c|c|}
\hline Item & $\begin{array}{l}\text { Absolute } \\
(\%)\end{array}$ & $\begin{array}{l}\text { Relative } \\
(\%)\end{array}$ & Item & $\begin{array}{l}\text { Absolute } \\
(\%)\end{array}$ & $\begin{array}{c}\text { Relative } \\
(\%)\end{array}$ \\
\hline Consumption to prevent environment pollution & 72.6 & 14.5 & Ethical consumption & 9.0 & 1.8 \\
\hline $\begin{array}{l}\text { Consumption to be helpful for health of me and } \\
\text { my family }\end{array}$ & 40.8 & 8.2 & $\begin{array}{l}\text { Organic agricultural product consump- } \\
\text { tion }\end{array}$ & 29.0 & 5.8 \\
\hline Consumption to discharge less carbon & 50.2 & 10.0 & $\begin{array}{l}\text { Consumption of products which are less } \\
\text { processed }\end{array}$ & 14.6 & 2.9 \\
\hline $\begin{array}{l}\text { Consumption of domestic goods rather than } \\
\text { imported goods }\end{array}$ & 16.6 & 3.3 & $\begin{array}{l}\text { Use and consumption of natural materials } \\
\text { and natural ingredients }\end{array}$ & 47.6 & 9.5 \\
\hline Consumption of Fair Trade products & 7.8 & 1.6 & $\begin{array}{l}\text { Reuse of resources and consumption of } \\
\text { recycled products }\end{array}$ & 61.0 & 12.2 \\
\hline $\begin{array}{l}\text { Consumption saving, consumption to use goods } \\
\text { for a long period of time }\end{array}$ & 53.2 & 10.6 & $\begin{array}{l}\text { Consumption for physical and mental } \\
\text { wellbeing }\end{array}$ & 11.8 & 2.4 \\
\hline $\begin{array}{l}\text { Consumption of products of a high quality } \\
\text { based on price }\end{array}$ & 16.4 & 3.3 & $\begin{array}{l}\text { Consumption that will not influense cli- } \\
\text { mate change }\end{array}$ & 25.8 & 5.2 \\
\hline $\begin{array}{l}\text { Consumption of products produced in the local } \\
\text { area }\end{array}$ & 6.8 & 1.4 & $\begin{array}{l}\text { Consumption of products that are harm- } \\
\text { less to the human body }\end{array}$ & 36.8 & 7.4 \\
\hline Total & 500 & 100 & & & \\
\hline
\end{tabular}




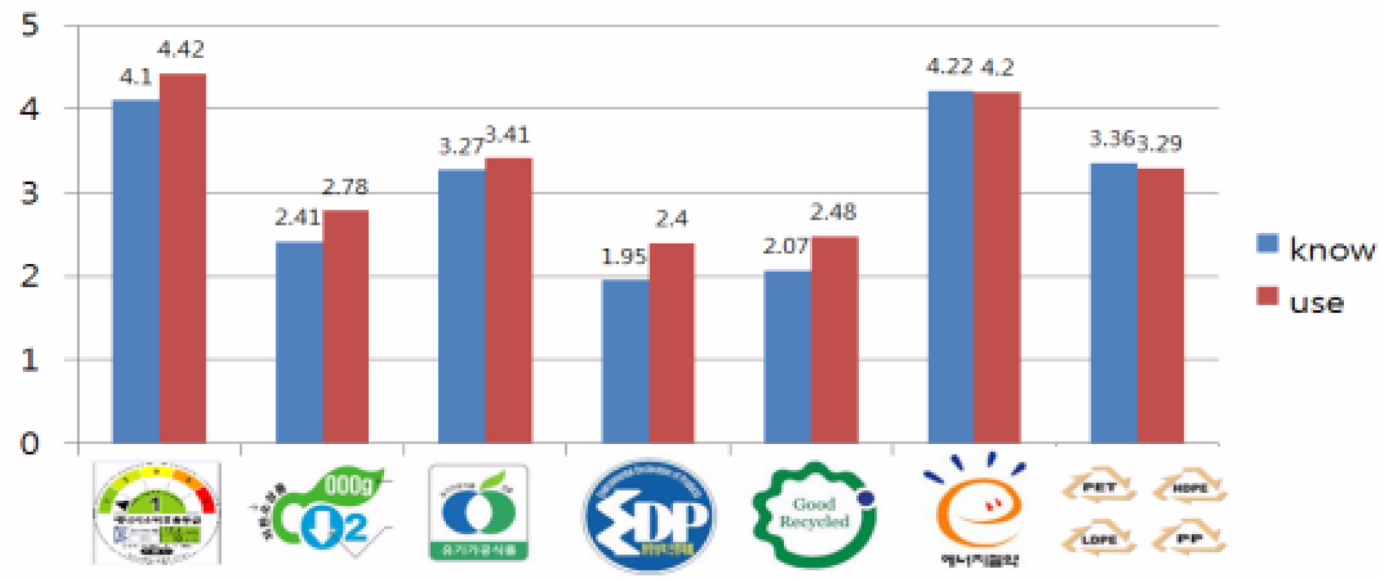

Figure 1. Consumer Awareness and Utilization about Green Consumption Information (mark).

Table 10. Awareness of the Green Terms

\begin{tabular}{|c|c|c|}
\hline Green terms & Answer & $\%$ of right answer \\
\hline 1. Organic farm products do not use any chemicals or fertilizer & No & 19.4 \\
\hline 2. Organic label applies only to food products & No & 55.2 \\
\hline 3. Biodegradation is the chemical dissolution of materials by bacteria or other biological means & Yes & 80.6 \\
\hline $\begin{array}{l}\text { 4. Carbon footprint is the total sets of greenhouse gas emissions caused by an organization, event, } \\
\text { product or person }\end{array}$ & Yes & 65.4 \\
\hline 5. Saving energy certified products expand less standby power & No & 14.2 \\
\hline 6. Eco-friendly mark is only for the products that reduce pollution or save resources & Yes & 79.8 \\
\hline 7. Energy-efficiency Low 1 means $50 \%$ of energy of Level 2 & No & 42.0 \\
\hline 8. Government decides the standards of all eco- certification & No & 26.0 \\
\hline 9. Energy-efficiency labeling is compulsory only for TV, Ref., Air-conditioner \& lighting instruments & No & 47.0 \\
\hline 10. GR mark means well-recycled products & Yes & 31.2 \\
\hline $\begin{array}{l}\text { 11. Food miles refers to the distance food is transported from the time of its production until it reaches } \\
\text { the consumer. }\end{array}$ & Yes & 79.0 \\
\hline 12. 'No-pollution' term can be used only for certified products. & No & 10.2 \\
\hline 13. 'Eco-friendly' products have a safe impact on the environment & No & 48.6 \\
\hline 14. PET or PP refers to certain materials used to make products & Yes & 72.4 \\
\hline $\begin{array}{l}\text { 15. Standby power refers to the electric power consumed by electronic and electrical appliances when } \\
\text { they are switched off }\end{array}$ & Yes & 45.4 \\
\hline
\end{tabular}

than the macro environment (climate or ecology).

2) Consumers awareness and usage of green claims A total of 7 green marks and 15 green terms were selected and used to understand how well consumers are aware of and use green claims. The first awareness measure examined how well consumers know each green marks. It was measured on a 5- point Likert scale. The most well known 2 marks by consumers were energy consumption efficiency mark and energy saving products mark while the least known ones were the environmental declaration products mark and good recycled product mark. Consumers tended to utilize the energy consumption efficiency mark most when they made a purchase; however, they seldom used 
good recycled product mark. Many consumers complaint that it was not easy to judge which ones were trustworthy green information because there were too much greenwashing information.

The second awareness measure was on how well consumers know the meaning of green terms. The explanation of 15 green terms were displayed and consumers were asked to check if the explanation was correct. Table 10 shows the percentage of respondents who perceived a right answer for each term.

The percentage of right answer for each term is low in general, from $10.2 \%$ to $80.6 \%$. The most well understood green term was biodegradation $(80.6 \%)$, follow by terms such as 'Eco-Friendly Mark' (79.8\%), 'food miles' (79.0\%), 'PET/PP label' (72.4\%). However, less than $20 \%$ of respondents were unaware of the meaning of 'organic farm foods', 'energy-saving certification', and 'usage of no-pollution term' Many consumers answered that they knew and used several green marks, but they seemed not to understand the meaning.

\section{CONCLUSION}

The market for green products has increased in recent years, and the importance of green claims is stressed as consumer information are required when selecting products. In order to expand green consumption, consumer information related to green products, which a consumer purchases, should be easily understood and be reliable. However, according to the Consumer Focus (2010), it was found that consumers could not check if products, packages or services had actual standalone advertising environmental characteristic. Consumers were confused by too many environmental claims and undifferentiated product packaging. This study examined the status of green claims provided in the market and how consumers perceive green consumption and green claims.

Consumer information required for the purchase of green products includes advertising through media such as TV or newspaper and product labeling. The media research and on-site research of this study showed many cases of non-certified green mark (company's self-design) and unclear marks, whether it was certified or not. There were many cases which were not certain on accreditation agency, validity period and contents of certification. There was no description of specific eco-friendly contents in case of terms that claim the eco-friendly attributes.

There were two reasons for consumer confusion in regards to green consumption. One reason was that consumers did not know the meaning of 'green consumption' and green claims. The study results showed that many consumers considered green consumption as 'organic agricultural products or natural product purchases' that were useful for the health and safety of consumers instead of for the reduction of carbon emissions or conservation of resources. In addition, consumers did not understand the meaning of green marks and green terms even though they reported that they were aware of them.

The second reasons for consumer confusion in the field of green consumption was greenwashing in the consumer market. Companies actively utilize environment marks to show environmental aspects. This can cause consumer confusion by attaching marks unrelated to environmental issues and marks manufactured in a similar form as national certification marks. The interest in eco-friendly products is growing; subsequently, the number of companies using the green marketing strategy to establish the eco-friendly image is also increasing. Relative to this environment, awareness in the increased false advertising are related to environment claims.

The following suggestions are made based on the results of this study First, consumers should be educated on the motivation and exact motivation to understand why green consumption is required. Increased worries and consumer mistrust over green consumption were partly due to the indiscriminate use of terms such as 'eco-friendly', 'no pollution', 'organic', 'green', 'cleanliness', 'nature/ natural' and 'safe to the human body. The important meaning of green consumption is a consumption behavior with the intention to reduce carbon emissions and conserve resources; therefore, education about green consumption should be made to encourage consumers 
to understand green product information.

When looking at the result of market investigation, in this study there is a requirement to examine if organic foods are a synonym for organic farming and green consumption. The terms of natural raw materials or ingredients were significantly used in pharmaceuticals and cosmetics; however, there is a requirement to examine if organic foods are a synonym for organic farming and green consumption to secure the standards about the meaning of natural. Materials that are natural go through several processing steps and are used for products in a transformed shape; the continued use of the term natural will confuse consumers.

Second, there is a requirement to strengthen the regulation in regards to company's own marks that can attach to products. Consumers did not differentiate the marks attached to products such as national certification, association certification or company's own certification. Therefore, the presentation method of certification marks and terms should be controlled and supplemented. A consumer should be able to understand accurately what information it implies in detail by looking at a certification mark since the accreditation agency, the validity period of certification and the contents of certification are labeled. For example, if the phrase of 'environmental friendly' is written, it describes that it is eco-friendly because it was not bleached with chlorine, which is known to produce hazardous substances in specific product packaging materials.

These results show the awareness in which green claims provided in the market was mostly inaccurate and not reliable, as well as with consumers make a wrong decisions based on inaccurate green information. Consumers may forgo the purchase of green products because of confusion that surrounds them. A company should help consumers obtain accurate information through the improvement of labeling methods that show the detailed meaning on terms and claims related to the environment. The government should establish the use of guidelines for claims and terms in order for a companies to provide accurate green information.

\section{REFERENCES}

Back, E. (2010). A study on the attitude and energy consumption behavior of low carbon green growth: in response to climate change. Master's thesis, Daegu Catholic University, Daegu, Korea.

Bae, S. Y. (2009). The role and challenges of green consumption, Seminar on Policies for green growth and green consumption, Korea Consumer Agency.

Bae, S. Y. (2010). 2010 green consumption trend and prospect. Consumer Policy Review, 9, 1-12.

Consumer Focus (2010). Green expectations: consumers' understanding of green claims in advertising. From http://www.consumerfocus.org.uk/assets/1/files/ 2009/06/Green-expectations-single-page.pdf

Cooper, T. (2000), Product development implications of sustainable consumption. The Design Journal, 3(2), 46-57.

DEFRA (2010). Assessment of green claims in marketing: Summary for Policy, UK.

FTC, http://www.ftc.gov/bcp/edu/microsites/energy/about_ guides.html, USA.

Han, Y. J. (2008). Japan's case centered on the status and challenges of eco-friendly products on the Internet, Ecoprism, 24.

Huh, K. (2009). How to keep consumer safety from imported goods. Consumer Culture studies, 12(2), 118.

Hwang, E. A. (2008). Study on driving measures for realizing sustainable energy consumption. Korea Consumer Agency.

Kang, S. (2009). A study on communication of consumer based on means-end chain model through eco-labels. Journal of the Korean Society of Design Culture, 15(4), 1-12.

Kim, M. G. (2012). A study on relationship between awareness of eco-label policy and consumption. Master's thesis, Sejong University, Seoul, Korea.

Korean Chamber of Commerce and Industry (2008). Carbon labelling: Labelling of greenhouse gas emission. Newsletter, 143.

Korean Ministry of Environment (2013). What is green consumption? http://eng.me.go.kr/content.do?method 
$=$ moveContent $\&$ menuCode $=$ res_cit_con_what

Lee, D. Y. (2000). Development of environment friendly consumer life style. Korean Consumer Agency.

Lee, K. A. \& Hwang, E. A. (2009). Study on measures to activate the information for practicing low-carbon green consumption. Korea Consumer Agency.

Lee, K. A., Hwang, E. A., \& Kim, S. C. (2010). A study on the measures to improve the information for purchasing green products. Korea Consumer Agency.

Moon, S. (2010). Green consumption cases and implications of leading countries. Forum Proceeding of 'How to Support Green Consumption'. MKE.

Zhang, Y. Y. (2011). A study of influential factors of eco-labelling products in consumers purchase intention. Master's thesis, Chonbuk National University, Chonbuk, Korea.

Kye, S., \& Kang, K. (1998). A study on the urban housewives' green-consumption behavior towards their value-orientation. Korean Family Resource Management Association, 2(1), 103-117.

Yoo, H., Lee, E., Kim, K., \& Cha, K. (2011). A contents analysis of the 'green' concept through a review of 21 Korean laws. Consumer Policy and Education Review, 7(3), 53-77.

Received February 1, 2013

Revised May 15, 2013

Accepted June 17, 2013 